\title{
"Fascism," the Relevant Past, and Monologues in the Face of Others
}

Konstantin A. Pakhalyuk

\author{
Konstantin A. Pakhalyuk, PhD in Political Science, \\ Russian State Institute of International Relations (Odintsovo Branch), Moscow, Russia \\ Department of Linguistics \\ Lecturer
}

ResearcherID: AAD-4008-2020

ORCID: 0000-0002-8473-4284

E-mail: kap1914@yandex.ru

Address: 76 Verdansky Preospect, Moscow

DOI: $10.31278 / 1810-6374-2021-19-2-184-195$

This analytical essay was written in response to Marlene Laruelle's article "Accusing Russia of Fascism: Politics around Russia's Belonging to Europe," published in Russia in Global Affairs, 18(4), 2020, pp. 100-123; D0I: 10.31278/1810-6374-2020-18-4-100-123.

Keywords: memory politics, macro-political identity, foreign policy, values.

rom a political point of view, the key purpose of any reference
to the past is not so much to substantiate concrete wording as
to form collective identities and/or provide moral justification
for certain political decisions. Therefore, one cannot but agree with
Marlene Laruelle that discussions, largely virtual, about World War
II and the role of the USSR in it, which flare up from time to time in
the European press, are closely related to the search for an answer to a 
more pressing question: Can modern Russia be considered part (albeit special) of some common European space? Her article, filled with propositions and observations some would gladly subscribe to, still gives food for thought due to its focus on academic debate with those who consider Russia fascist or seek analogies between Putin's Russia and Hitler's Germany.

The proposed reasoning, convincing and witty, is obviously intended for the "Western" reader but looks rather redundant in the context of the Russian journalistic mainstream. Naturally, broad historical analogies will easily be debunked by any more or less professional historian, but the point is that these historical metaphors come not so much from the world of science (the cited works of V. Inozemtsev and T. Snyder can hardly be considered strictly academic), but from the world of journalism and public intellectuals, and therefore their regular replication clearly indicates that these images have explanatory potential, at least for their authors and their readers.

Finding out why they are convincing for someone is no less important than showing the invalidity of such discursive games. Therefore, while understanding that my essay may not be comprehensive, I would still like to focus on two points: the very attempt to describe modern Russia as fascist, and the fact that M. Laruelle's article essentially boiled down to discussing certain facts from the past and using "historical arguments" in modern journalism.

For me, the latter undoubtedly indicates that history has become one of the public languages (discourses) in the political life of not only Russia, but also other European countries, and the use of this language, be it newspapers or academic journals, implies a certain meaning for those who participate in such discussions. And if so, historical analogies themselves become inevitable, and multiplying historical questions, assessments and problems are politicized and turned into the subject of political struggle.

This article alone is not enough to say how much the "fascist Russia" discourse is important for Europe (the author does not provide any evidence), but the choice of arguments used is certainly not a question of pure interest: key goals for the "historical component" of Russia's 
foreign policy throughout the past decade have been based on the "inadmissibility of rewriting history" and the need to "protect the historical memory of the Soviet people's feat," rather than attempts to find counterarguments against these accusations. Accusations of fascism sound so wild for many representatives of public and political forces in Russia that they end up in a "blind zone" and probably never get a proper assessment.

For a decade, Russian foreign policy institutions and related public organizations have been keeping their focus on the role Russia (the Soviet Union, the Russian Empire) played in European affairs: liberation from Nazism gets priority, but the set of historical episodes also includes references to the Napoleonic Wars and World War I (virtue as a reliable ally), contributions to common culture, and scientific achievements (space exploration, Russian literature, art, etc.).

Moreover, this is true not only of diplomats, publicists, and mediaoriented events, but also of an active memorial policy-more than a hundred monuments and other memorial plaques unveiled around the world (mainly in Europe). Such an emphasis on the demonstration of one's own righteousness, indeed, makes it difficult not only to study the "complex aspects of the past," but also to build common memory spaces.

But linking the Europeanness of my country solely to the discussion of fascism would be too bold a move. Moreover, the very attempt to combine these two topics looks to me like a trick designed to force Russia (officials, journalists, intellectuals) to talk, first of all, about whether or not it is worthy of such recognition, and whether or not it is ready to accept a certain standard (with the negative sign). Discussing this issue seriously at the political level and on the newspaper front pages would mean taking a deliberately weak position. Eventually, as political analyst V. Morozov writes, a rather strong discursive image of a "true"/"false" Europe formed in the Russian public space in the 2000s (Morozov, 2009), according to which certain facts from the life of other European countries (for example, ethnonationalism in the Baltic states or same-sex marriages) are interpreted as a departure of these communities from the "true European path." Accordingly, any 
accusation of "fascism" will be parried with "We hear this from a false Europe." This can only produce billingsgate.

Therefore, in the realities of the third decade of the 21st century, the discussion about the European nature of Russia should probably take the form of dialogue, where both sides are ready to partly change themselves and partly recognize both their common features and distinctions. The EU's experience of dealing with the collective past speaks in favor of this approach. By and large, the pan-European collective discussion on World War II, to which M. Laruelle constantly refers, is not only about facts and interpretations, but also about ethical systems.

The call by Western European politicians and public intellectuals for admitting moral and political responsibility for their own crimes committed in the past has puzzled a number of politicians and public figures (mainly among local national conservatives) in Central and Eastern Europe. They would like to discuss not so much collective responsibility for the complicity of their countrymen in Nazi crimes (or in repressive policies of the socialist period) as their suffering as "victims of the occupation" regardless of whether it was under Hitler or Stalin.

All this caused conflict in the ethical foundation of the panEuropean collective memory, and provoked real competition between victims (see: Miller, 2016; Leggewie and Lang, 2011; Assman, 2016). However, these objective difficulties triggering heated debates are inextricably connected with the European integration project and the construction of a common political space. This is a collective discussion about the common past for the sake of a common future, with commitment, at least declarative, to such universal values as democracy and human rights. Contradictions, disputes, and conflicts are unavoidable in this case, but they are caused by the original political plan to live together.

And this is where we come close to the main problem. Russia is not a full-fledged participant in this discussion simply because it is not part of the European integration project, especially since 2014 when deep political differences between them became apparent. On 
the European track, Russia's foreign policy and rhetoric have long been purely pragmatic and focused on the pursuit of specific interests. Moreover, at the official level, Russia does not want to speak with the rest of the world in the language of universalism and universal values, preferring the language of virtues; ${ }^{1}$ since the latter always requires concrete examples and patterns of behavior, historical plots come quite handy here-historical reasoning is designed to emphasize Russia's "age-long" virtue and make it "natural" and "enduring" ("this is how it was, therefore it is true, and so we can do this again"). Thus the appeal to history in recent years is a way to fill the value gap by invoking the historical righteousness of Russia - this is a kind of language, rhetoric, discourse that responds sharply to the political situation.

This is why it would be reasonable to talk not so much about differences in narratives or some "fundamental" cultural dissimilarities, and not so much about the struggle for the right to determine "who is the fascist here," as about the political confrontation itself, which is getting entrenched in historical rhetoric. Labeling, loaded emotionally and semantically, such as accusing Russia of fascism, is one of the communicative tactics, but its correct analysis requires a strategic context. And if one tries, for example, to conceptualize heated quasihistorical discussions (to be more precise, "monologues in the face of others") now underway between Russia, on the one hand, and Poland and the Baltic countries, on the other, then this confrontation will be used on both sides by local national conservatives seeking to gain domestic political advantages by actualizing the image of the enemy.

Vladimir Putin's well-known speech in December 2019 (with an emphasis on the role of interwar Poland's political elites in unleashing World War II and the participation of Poles in the Holocaust) was recoded in Poland as a direct accusation of "deadly historical sins" leveled against the Poles. This fueled anti-Russian rhetoric and benefitted the ruling party. At the same time, the demolition of Soviet monuments and statements by Polish politicians and journalists that belittle the role of the Red Army are effectively used in Russia as clear

This choice is partly motivated by the Soviet legacy and has cultural and historical roots. See: Harhordin, 2011, p. 269-312. 
evidence that an external enemy threatening the memory of the Victory really exists.

Since it was the historical past that became the main "assembly tool" for the Russian nation in the 2010s (creating both the civic cult of the Great Patriotic War and special political correctness practices) and since it has been assembled by the conservatives, we cannot underestimate the significance of such "memorial conflicts." The more Soviet monuments are destroyed abroad and the louder the voices of politically motivated critics (like those playing with the label of "fascism"), the sooner all this will be used in Russia by certain powerwielding elites and the conservative public to strengthen macropolitical identity with a strong isolationist component.

However, it would be wrong to essentialize these discussions and view them as insurmountable reasons for confrontation. With the political will, if it is impossible to agree on common wording, it is always possible to politely acknowledge disagreements. In fact, in 2009, socialist-era monuments stood in Poland as before and political leaders were able to find a common language. At the ceremony marking the 70th anniversary of the start of World War II, held near Gdansk, then Prime Minister Vladimir Putin spoke about the Red Army's role in liberating the Polish people from Nazism, and Polish President Donald Tusk, while acknowledging what had been said, noted that the liberation from Nazism could hardly be recognized as complete freedom. The recorded difference in approaches was not regarded as a "memorial war" or a reason for further attacks against each other.

And if one imagines that-all of a sudden! - the EU and Russia find the political will for rapprochement in the near future, then the search for the "historical language" that could express the commonality of our destinies would hardly have any relation to discussions about fascism or the search for accommodating wording to describe well-known "difficult issues" in the history of World War II. It is not so difficult to work out such wording for political declarations or mourning/ solemn events. It is much more difficult to imagine integration at the level of "memorial policy" - a real cultural dialogue, not numerous monologues in others' presence. 
If Russia is required to accept certain elements of the ethics of responsibility (at least for a number of ugly and criminal actions of the Stalin era), then, in return, Russia will certainly demand symbolic recognition of the Red Army's role as the victor and liberator (which may raise the question of developing ethics of appreciation). Talking about the victims of Nazism, which has actually turned into a wider discussion in modern Europe about the victims of state crimes, will be a challenge, too. Specific features of Europe's memorial policies in this respect remain a mystery even for many Russian specialists, and the concept of the Holocaust had become more or less known to the general public only by the end of 2010s.

Key problems will not be associated with the need to admit the fact that someone could suffer at the hands of the Soviet government, but with the very need to understand the rationale behind the commemoration of victims, which is fundamentally different from the logic underlying the commemoration of heroes, which is so customary for Russian people. Going back to the issue of Nazi crimes, it will be important for Russia that specific aspects of the suffering experienced by the entire Soviet population in the occupied territories be recognized since they went through the inferno of special terror unleashed by Hitler as part of his war of annihilation in the East. This topic has been getting more and more attention at the official level in Russia since the end of 2020. Time will tell whether this turns into another competition of victims or becomes the basis for some common memorial initiatives.

Another aspect of M. Laruelle's article, which I would like to point out, concerns the very attempt to define Russia as a fascist country. The label "fascism" not only seems to reflect a certain political and journalistic orientation of the authors who use it, but also refers to a deeper problem, namely the lack of conceptualizing descriptions of modern Russia, which can be felt even among Russian intellectuals.

The abundance of discussions, observations, conceptual approaches or brilliant individual studies should not be confusing. Going into particulars or abstract conversations about "civilizational types," which frequently devolve into an analysis of historical trajectory (many intellectuals have a tendency to do this regardless of academic 
background and political preferences) essentially cannot fill this gap. At the same time, proposing conceptualization and making a detailed analysis based on it are completely different things.

The degradation of the public space as a place for open dialogue could not but have consequences: pro-government media working for the general public present Russia as a besieged fortress, and structure discussions about internal developments through a discourse that praises various forms of non-freedom and seeks to reconcile people with it.

Opposition media fiercely attack what is portrayed as a monolithic power construction, each step of which, they claim, signifies an ever greater moral collapse and degradation, inevitably predetermining a general downfall of the regime.

At a more conceptual level, the level of public intellectuals, the discussion about ongoing processes revolves around the concepts and images of 'state,' 'empire,' and 'system of power,' as well as the clarification of various kinds of neo-patrimonial relations. Inevitably, in the center is some sort of totalizing, hegemonic, state-forming entity; due to the difference in political tastes, some take it as a given (which does not rule out the need for its "tuning"), while others see it as a curse.

As a result, the discussion about the state (is it a normal/abnormal state, total, absent, or is it just a smokescreen for the "strong-arm government," "system," "hegemony," "deep people" or something else?, etc.) turns out to be difficult even for Russians, let alone an outside observer, especially amid active militant rhetoric on behalf of the state, with frequent references to victories and conservative values, and criticism of liberalism.

All this can really make an outside observer talk about fascism in modern Russia or deliberately play on such fears (for example, aforementioned V. Inozemtsev writes about "soft fascism," exploring it through the big role of the state in the life of society and the economy, active militaristic rhetoric and state propaganda; however, he himself is against direct comparisons with Nazi Germany (Inozemvtev, 2019, pp. 97-109)). 
That is why M. Laruelle's article is quite good where it exposes attempts to slap a "fascist label" on Russia, and raises questions where the author has to make a certain description (if not fascism, then what?). I believe this is partly due to the underestimation of the important aspects of the nationalization of public and economic life, which is accompanied by: 1) deliberate politicization of culture (including history) and depoliticization of other areas (Budrajtskis, 2020); and 2) increased rental attitudes (not just the struggle of social groups for benefits or subsidies, but also the behavior of companies whose profits do not depend on market competition, but on closeness to the government (Fishman, Mart'yanov and Davydov, 2019).

Looking through this lens, many elements of the only "fascist component" discovered in modern Russia, that is, "a constituted paramilitary culture directly supported by state institutions," do not appear to be so terrible. For example, the figure 700,000 employees of private security companies was taken from one of the Russian Guard documents, which records the market of private security services it controls; 400,000 Youth Army members is also pure bureaucratic fantasy reflecting the efforts of a certain agency to create an expanded system of patriotic education (since the administrative and command resource has been used most actively in creating the Youth Army, taking these estimates seriously would be overly optimistic); and 100,000 Cossacks is a no less rounded and bureaucratic figure, whereas in reality it is hardly a monolithic community, but a complex system of communication between the state and various social groups that pursue completely different interests (from subsidizing leisure activities to obtaining economic privileges).

As the cultural space is being deliberately politicized, the dialogue between the state and non-state actors, groups and associations tends to appeal increasingly often to certain cultural, metaphysical, historical, and other realities. Given the growing rental attitudes in society, we should not be surprised to see that this dialogue looks more and more like a non-freedom discourse. Therefore when analyzing individual texts created within the framework of this discussion it would be methodologically hasty to automatically understand them literally as 
an expression of some inviolable positions and stable identities. Cutting off a pragmatic context in the absence of a sufficiently broad sample of sources may lead to serious errors that will force the researcher to turn particulars into fundamental conclusions.

Perhaps this is why at the very end M. Laruelle came to a very strange conclusion that "for Russia, 'normalcy' refers to the Cold War decades." Such a statement might have been prompted by her analysis of a limited number of texts, but a different approach, different sources or a different analysis method would not produce the same conclusions.

In fact, our study of all of Putin's "historical" speeches in 20122018 shows that, with the exception of the Great Patriotic War, he was most active in actualizing the pre-revolutionary, imperial past, not other periods of the Soviet era (Pakhalyuk, 2018). The study of postwar Soviet history also remains marginal for key pro-state historical policy actors (the Russian Historical and Russian Military-Historical Societies). Similarly, sociological surveys show a clear relationship between different generations: the less a person was socialized in the Soviet period, the less often he says that he would want his children to grow up in Soviet times (Radayev, 2019, p. 118).

Therefore, if someone views the Brezhnev era as a standard of normalcy, then it would be worth trying to understand in what particular context he does so. There is a hypothesis that this is a generational feature (Gelman, 2019, p. 32), but it requires verification. Historian K. Kobrin has put forward a thesis, based on several examples, that "Soviet nostalgia" is culturally conditioned. He wrote about a network of cultural interpretations and images that were created mainly by the Moscow intelligentsia during the period of "stagnation" in the USSR and became the "assembly point" for post-Soviet people who began to perceive these cultural products as real history. What was intended to performatively visualize successes in building socialism (while being aware that objective reality falls short of that) is now mistakenly seen as evidence that it was actually built (Kobrin, 2017). Or if we trust our intuition that since 1991 we have been living in a state of emergency, then images from the Brezhnev era can, indeed, be regarded as a worthy offer amid the shortage of "normalcy." 
In any case, the meanings that load history, and culture, in modern Russia are increasingly determined by the internal collective discussion, and therefore are less and less sensitive to being labeled abroad as "fascist." When finishing this article, I came across fresh data from the Levada Center's nationwide survey. They indicate that while $52 \%$ of Russians considered Russia a European country in 2008 now only 29\% do so. Similarly, the number of people who call themselves Europeans has decreased from $35 \%$ before to $27 \%$ now (Levada Center, 2021). If this tendency continues, then any talk of whether Russia should build some common memory space with other countries will become senseless and turn into a subject of idle discussion for a bunch of intellectuals.

\section{References}

Assman, A., 2016. Novoye nedovolstvo memorialnoi kulturoi [New Dissatisfaction with Memory Culture]. Moscow: Novoye literaturnoye obozrenie.

Budraitskis, I., 2020. Mir, kotory postroil Hantington i v kotorom zhivem vse my [The World that Huntington Built and We All Live In]. Moscow: Tsiolkovsky.

Fishman, L., Martyanov, V. and Davydov, D., 2019. Rentnoe obshchestvo. V teni truda, kapitala i demokratii [Rental Society. In the Shadow of Labor, Capital and Democracy]. Moscow: Izdatelsky dom Vysshej shkoly ekonomiki.

Gelman, V.YA., 2019. "Nedostoinoye pravlenie". Politika v sovremennoi Rossii ["Unworthy Rule." Politics in Modern Russia]. St. Petersburg: European University in St. Petersburg.

Harhordin, O., 2011. Osnovnye ponyatiya rossiskoi politiki [Basic Concepts of Russian Politics]. Moscow: Novoye literaturnoye obozrenie.

Inozemtsev, V., 2009. Nesovremennaya strana. Rossiya $v$ mire XXI veka [An Outdated Country. Russia in the 21st-Century World]. Moscow: Alpina.

Kobrin, K., 2017. Postsovetsky mavzolei proshlogo [Post-Soviet Mausoleum of the Past]. Moscow: Novoye literaturnoye obozrenie.

Leggewie, K. and Lang A., 2011. Der Kampf um die europäische Erinnerung. München.

Levada Center, 2021. Rossiya i Evropa [Russia and Europe]. Levada Center, 18 March. Available at <www.levada.ru/2021/03/18/rossiya-i-evropa-2/?utm 
source=mailpoet\&utm_medium $=$ email\&utm_campaign=newsletter-posttitle_81> [Accessed 18 March 2021].

Miller, A., 2016. Politika pamyati v postkommunisticheskoi Evrope i ee vozdeistvie na evropeiskuyu kulturu pamyati [Politics of Memory in PostCommunist Europe and Its Impact on European Culture of Memory]. Politiea. The Journal of Political Theory, Political Philosophy and Sociology of Politics, 1, pp. 111-121. DOI: 10.30570/2078-5089-2016-80-1-111-121.

Morozov, V.E., 2009. Rossiya i drugiye. Identichnost i granitsy politicheskogo soobshchestva [Russia and the Others. Identity and Boundaries of the political Community]. Moscow: Novoye literaturnoye obozrenie.

Pakhalyuk, K.A., 2018. Istoricheskoye proshloye kak osnovanie rossiyskoi politii. Na primere vystuplenii Vladimira Putina v 2012-2018 gg. [Historical Past as the Basis of Russian Politics. An Analysis of Vladimir Putin's Speeches in 20122018]. Politiea. The Journal of Political Theory, Political Philosophy and Sociology of Politics, 4. pp. 6-31. DOI: 10.30570/2078-5089-2018-91-4-6-31

Radayev, V. 2019. Millenialy: Kak menyaetsya rossiiskoye obshchestvo [Millennials: How Russian Society Is Changing]. Moscow: Izdatelsky dom Vysshei shkoly ekonomiki. 